\title{
The Actual Situation of Sheep's Wool Capitalization in Romania
}

\author{
Iacob FLOREA
}

Technical University of Cluj-Napoca, Faculty of Civil Engineering, Department of Civil Constructions and Management, 15 Constantin Daicoviciu Street, 400020, Cluj-Napoca, Romania

* corresponding author: iacob.florea@ccm.utcluj.ro

Bulletin UASVM Animal Science and Biotechnologies 75(2)/ 2018

Print ISSN 1843-5262; Electronic ISSN 1843-536X

DOI:10.15835/buasvmcn-asb: 2018.0024

\begin{abstract}
Sheep farming always made a special contribution to the development of practicing people, improving the standard of living, effects also known by Romanians, even if the number of sheep and implicitly the amount of wool had fluctuations over time. After the 90s, demand for wool in the textile industry began to decline and the wool has not been widely capitalized in Romania, being abandoned by farmers, even burned. The aim of this study is to provide solutions for wool collection in an organized manner and as profitable as possible for Romanians at national level, avoiding wool waste and chaotic export. The collection centers are unevenly distributed accros the country and there are some counties where sheep wool is not collected. With the proposed solution of locating other collection centers or distributing the authorized ones, it is possible to capitalize the entire wool resource available in Romania.
\end{abstract}

Keywords: actual sheep, capitalization, collection centers, sheep wool

\section{INTRODUCTION}

The aim of this study is to provide solutions for the capitalization of sheep wool in an organized manner at national level, avoiding wool waste. Farmers should also be encouraged to practice the sheep farming, including proper care of animals, in order to obtain a high quality wool.

The highest density of sheep is found in the most favorable areas for their growth, with a temperate oceanic climate, between the northern and southern latitudes of $40^{\circ} \mathrm{C}$. Sheep breeds with fine wool and those for sheepskin prefer areas with a warm climate.

According to Pop et al (1983), this is why Merino breed is the most common in both hemispheres around the $40^{\circ} \mathrm{C}$ parallel, with temperatures between $10^{\circ} \mathrm{C}$ and $20^{\circ} \mathrm{C}$ and precipitations between 250 and $700 \mathrm{~mm}$ per year. However, sheep are sensitive to high variations in humidity and temperature. Both the cold and humid climate and the warm and humid climate endanger their health and productivity and these climatic conditions limit their area of spreading (Doroftei, 2006).

The temperate climate, the geographical configuration, the large grassland areas but also the diversity of products obtained from sheep have determined their spread in all the relief areas, thus covering the whole country (Pascal, 1998).

Ever since the start of state formation, the history of the Romanians speaks about the sheep breeding on the territory of our country and about the contribution of this species to the Romanian people's language and traditions unity.

Today there are over 750 sheep breeds in the world (Pascal, 1998), thus managing to meet al. the requirements that the beneficiaries had of this complex species through the variety of products 
offered to humans: wool, milk, meat, sheepskin and fleeces.

Pascal (1998), told that in our country, until the second half of the 19th century, breeds and late types of sheep were growing, rustic sheep that acclimatize very well to temperate continental climate, having high resistance to diseases. Among these types of sheep are: Țurcana, different types of Stogoșă and fewer types of Țigaie, they were untreated flocks with high organic resistance, high capacity to adapt to environmental conditions and enhanced rusticity. The wool from the Turcana sheep is coarse and has the longest thread being followed by the Stogosa sheep with semi-coarse wool and Tigaie sheep with semi-fine wool. Merinos is added to this, a sheep that has fine wool, a sheep breed imported and crossed with domestic sheep.

Until the end of the 17th century, coarse wool production was predominant in Romania but to a lesser extent and only for semi-fine wool. The need for quality raw material, especially Merinos fine wool, has grown along with the improvement and development of the textile industry.

The second place in Romania was owned by Tigaie sheep, but after 1989 their number decreased by $44 \%$ due to the loss of profitability of wool production according to Ilișiu et al. (2013). In Romania, sheep breeding is $99,85 \%$ in the private sector, and only $0,15 \%$ of the total flocks remained in the state sector. The average size of a flock of sheep is $250-500$ sheep heads.

Compared to other species, sheep require

lower requirements in terms of shelter and care, and as food they consume a range of fodder products that can not be effectively harnessed by other farm animal species (Pop et al., 1983).

After the 90s, demand for all types of wool began to decrease and implicitly wool has not been fully capitalized in Romania, it was abandoned by farmers and the state has not supported this sector anymore, wool becoming worthless compared to other fibers.

\section{STATISTICS AND ANALYSIS}

Over the past two centuries, sheep farming for wool has expanded both numerically and as a surface and this expansion has taken place worldwide, largely depending on geoclimatic conditions. In turn, both climate and vegetation conditions, as well as the development of socio- economic requirements, have led to a great variety of sheep breeds under the influence of natural and artificial selection.

Starting with 1860, the first statistical data on sheep flocks in Romania appear. At that time, the sheep's total was 4.411 thousand heads, followed by an upward trend over the next 100 years (Figure 1), with the peak reached in 1924 when sheep flock tripled (Nica et al., 1965).

After World War II, sheep flocks in Romania recorded significant increases and after only six decades, due to internationally favorable circumstances, in 1985 (Figure 2) there was a total of 18,6 million sheep, representing the maximum ever reached by our country (FAO, 2018).

After this period, a numerical decline of the Romanian sheep starts because of the disestablishment of the large state or cooperative farms and because of the change of ownership form on the land fund.

Thus the great breeders have reduced their livestock, not having pastures, grasslands and farmlands. The interest in wool production in favor of meat production also declined, and 90\% of the living sheep have been sold on international markets, especially in the Near East and Middle East.

Due to the fact that there is no outlet, the price of wool given by the purchasers is extremely low, and those who buy it for export try to lower the price by invoking reasons such as: the wool is of poor quality, it is not properly maintained, dirty and with a lot of plant impurities, all because of the sheep farmers who do not offer the best conditions to the sheep.

As for the quality of wool, these buyers are right because after 1989 the pastures in Romania are no longer maintained and the wool is filled with these plant impurities (thistles, burrs, etc.). That is why, before the $90 \mathrm{~s}$, all the pastures were maintained by the villagers who cut the sprouts that appeared during the year, anthills and other thorns/thistles which get attached to the sheep's wool during grazing.

At present, in Romania the price for shearing a sheep is 2,5 lei, and the amount of wool obtained from a sheep is around $2,25 \mathrm{~kg}$, so the sheepherder should receive at least 1,11 lei / $\mathrm{kg}$ in order to pay the sheep shearing, which is in fact most of the time impossible. 


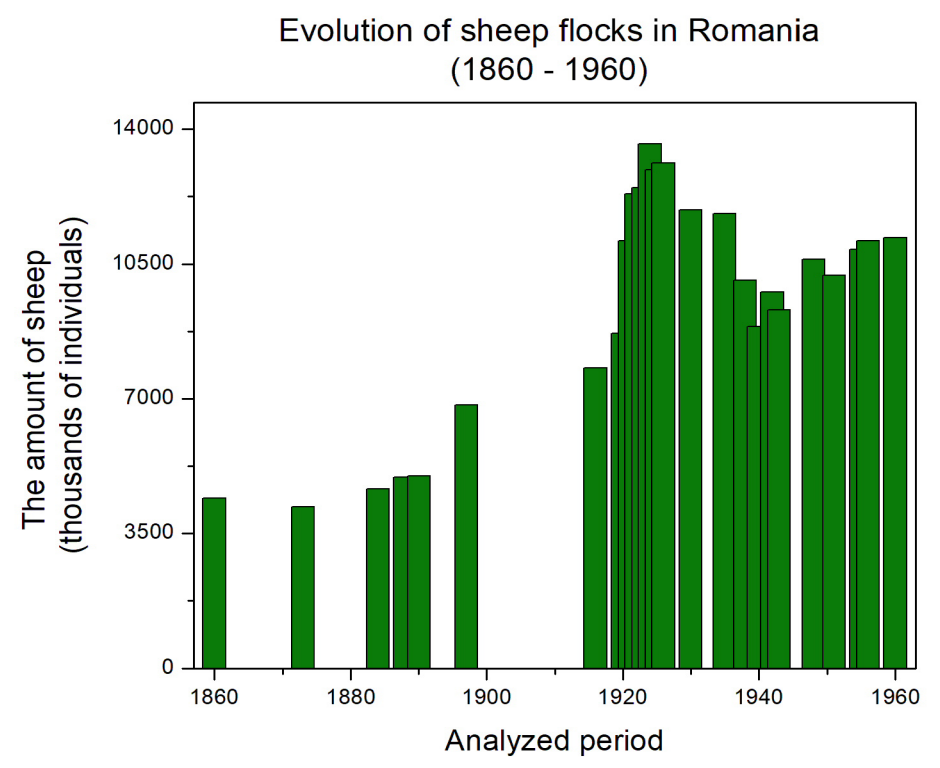

Figure 1. Evolution of sheep flocks in Romania during the period 1860-1960

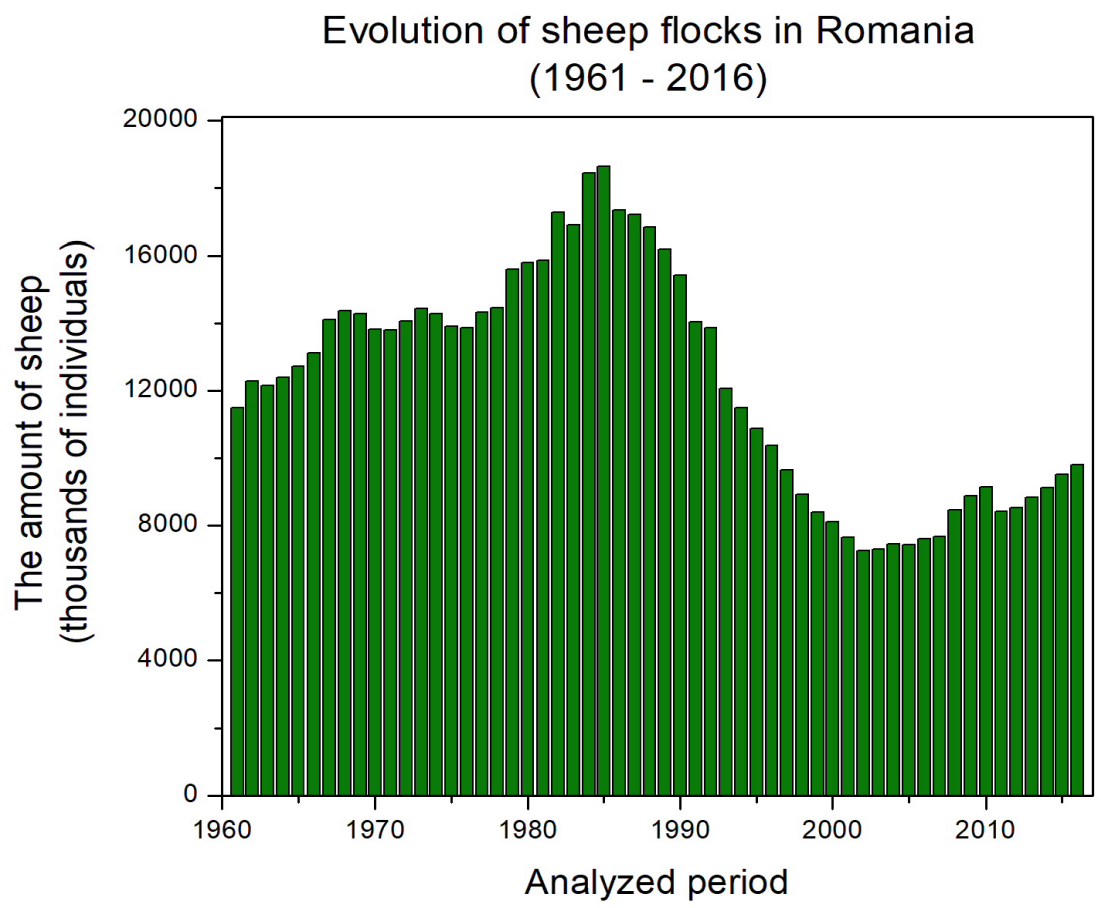

Figure 2. Evolution of sheep flocks in Romania during the period 1961-2016

Because of this imbalance between demand and supply, in 1999, in Sibiu County, the first wool collection center has been set up by a Turkish citizen established in Romania. This collection center has a storage capacity of 50 tons per day and exports raw wool in countries of the West and East Europe (Tolga, 2018).

Sheep farmers located away from Sibiu and even those in the surroundings, who do not get a good price in order to be able to pay the sheep shearing and wool transportation to the center, 
choose to abandon the wool in the field, being later one incinerated. Because the wool burns hard enough, it is mixed with hay or splashed with diesel and the combustion results in pollutant products for the environment. For these reasons and because it requires costs to dispense with it, farmers consider wool to be a waste.

\section{DISCUSSIONS}

Regardless of the situation, the farmers kept breeding sheep and Romania currently ranks 3rd in Europe, after United Kingdom and Spain, with nearly 10 million sheep. If before the 90s, the counties with most sheep were located in the South part of the country, the top counties are now in Transilvania. Romania has great grazing availability, but also access to modern technology for the capitalization of sheep wool, which makes pastures easier to maintain and the wool can be purchased mechanically, while creating new jobs.

Considering the difficult situation of Romania regarding the capitalization of sheep wool, in July 2017, the Government of Romania, through the Ministry of Agriculture and Rural Development, publishes the Government Decision no. 500/2017 on the approval of the scheme 'Ajutor de minimis pentru aplicarea programului de susținere a crescătorilor de ovine pentru comercializarea lânii' (G.D. 500/2017).

Any breeder of sheep that holds a manufacturer certificate and, based on Law no. 145/2014, any authorised person, individual enterprise and family enterprise which are constituted under the provisions of Government Emergency Ordinance no. 44/2008 or any legal person can benefit from this legislation. The eligibility for this "de minimis" aid is conditional, the sheep breeder must possess a holding registered in the National holding register and the evidence of wool quantity marketing (G.D. 500/2017).

The Ministry of Agriculture has placed the sheep wool collection centers in every county and even more centers in the same county according to the number of sheep. Based on this G.D. 500/2017, a number of 22 sheep wool collection centers (Figure 3) are authorized by the Ministry of Agriculture and Rural Development, which serve only 10 counties (MADR, 2018).

A first step was taken, locally in this counties, the sheep wool collection problem was solved, but there are still more than $75 \%$ of the country's surface where farmers do not have access to an authorized collection center. According to the National Institute for Statistics, the availability of sheep's wool is shown in (Figure 4), corresponding to 2016, with a total of 22.277 tons (INS, 2018).

From the information made public by the ministry on 04.01.2018, respectively on 28.02.2018, the storage capacity of the authorized collection centers is 25.050 tons, respectively 23.570 tons (MADR, 2018).

Authorized collection centers have different storage capacities from 20 tons to 9.000 tons, but more than half of them have the storage capacity below 500 tons. For this reason, each proposed center is correlated with the amount of wool available in that county and the maximum distance of $100 \mathrm{~km}$ from it.

The Agricultural Directorate of each county will take over from farmers the evidence of selling the sheep's wool to an authorized center, which is a prerequisite for obtaining the state subsidy. In order to solve the issue of wool collection across the country, in correlation with the existing centers, I propose in (Figure 5) the optimization of their location and the establishment of new centers. The total number of centers is 53 distributed as fellow in counties with more than 1.000 tons of wool three centers are proposed, for counties with more than 700 tons of wool two centers are proposed and for the other counties only one center is proposed. The storage capacity may vary from one to another, depending on the surface and the equipment they have for sorting and baling sheep's wool.

With the proposed solution of distributing authorized centers around Sibiu and Constanta counties, but also by establishing new collection centers in other counties, the entire wool ressource available in Romania can be capitalized.

\section{CONCLUSIONS}

When spinning mills and carpet factories closed, after the 90s, where sheep wool was the basic raw material in this industry, wool is no longer of interest on the Romanian market and wool products are replaced by synthetic materials from our country or imported from other countries.

The quality of sheep's wool, which is a problem on the market, may increase if the sheep farms' associations would charge a fee for every farmer depending on the grazed area and the 


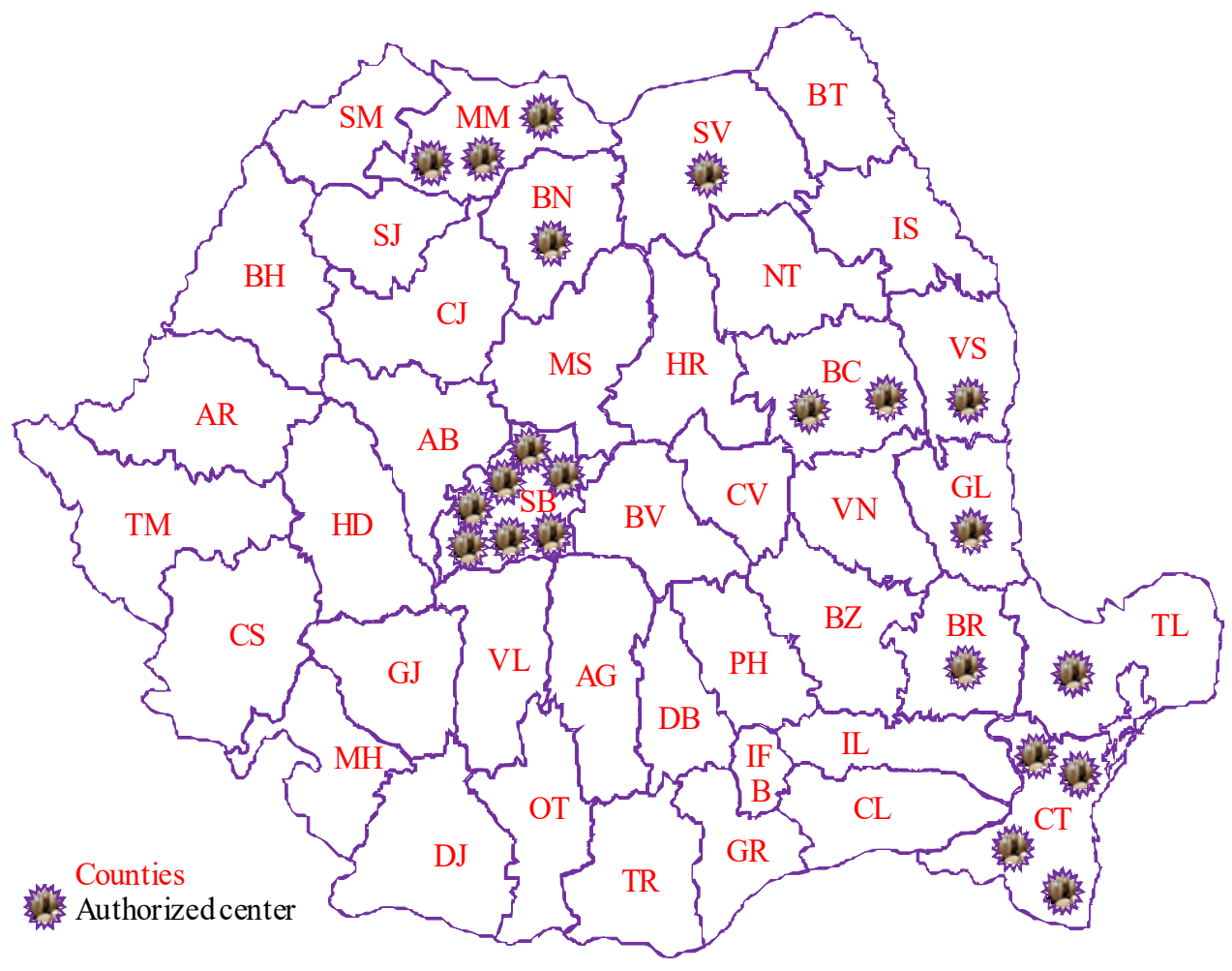

Figure 3. Current situation of nationally authorized collection centers

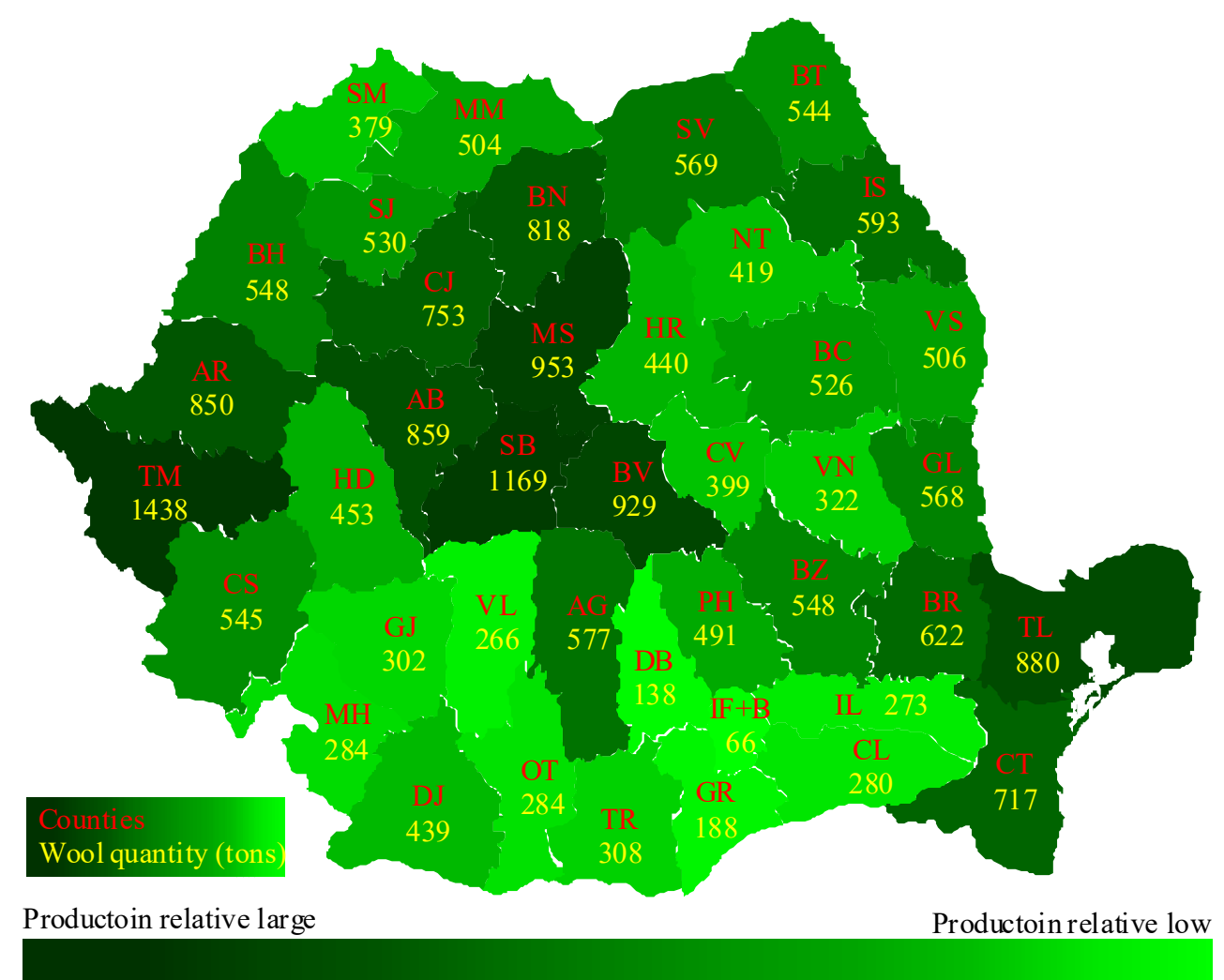

Figure 4. Production of sheep wool at national level, related to 2016 (tons) 


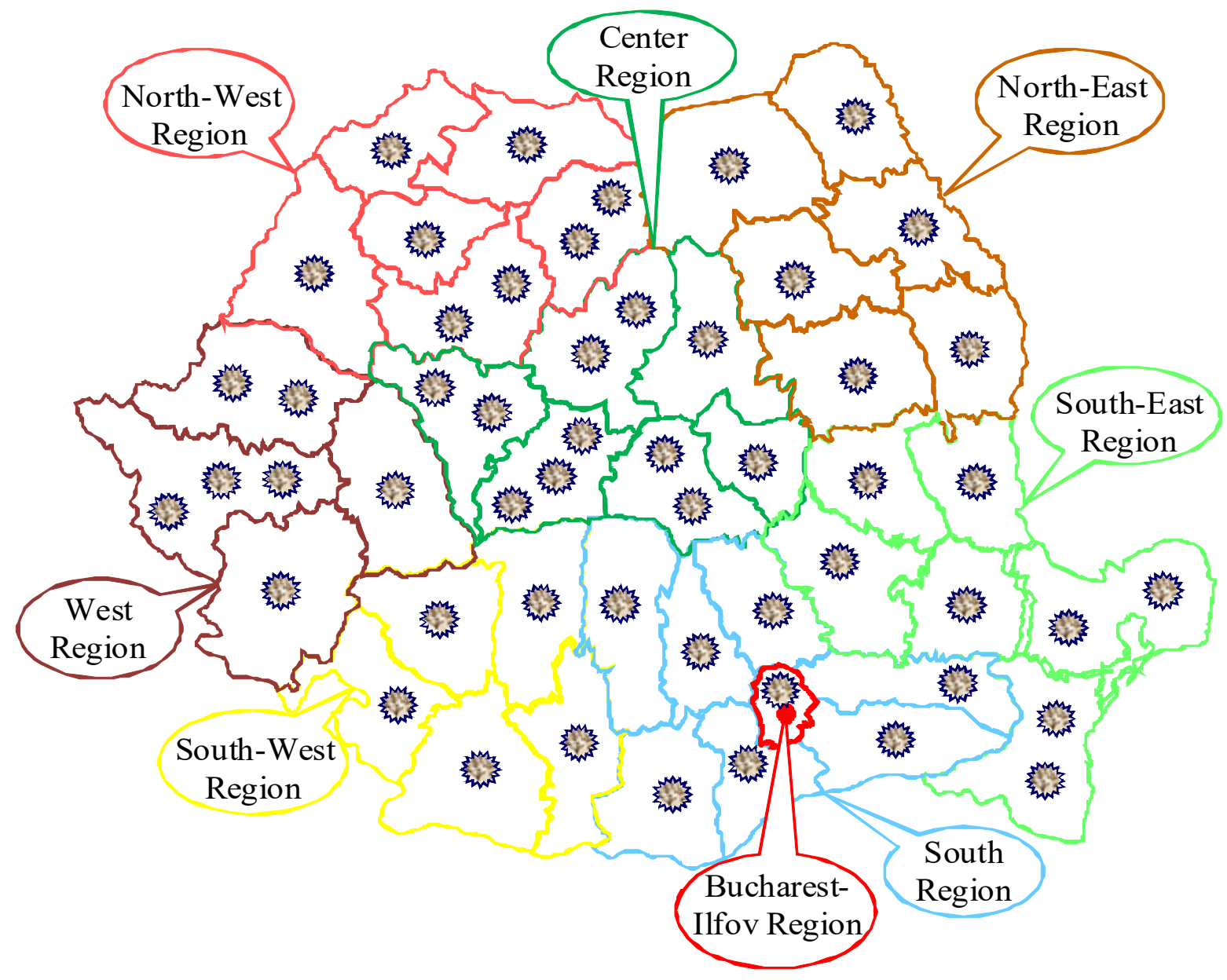

Figure 5. Proposed situation for distribution of existing centers and authorization of other centers

number of sheep they own, for the purchase of equipment needed for grassland maintenance by the associations.

By optimizing the location of the 53 wool collection centers, the cost reduction for wool transport to collection centers by farmers is justified.

Once the wool is collected, the Government of Romania must find a way to capitalize wool, so as to pursue the Romania's economic interests.

If this is taken into account, then the wool will certainly not be thrown into the field or burned anymore and this would lead to industry recovery and economic growth in domains that currently do not use wool as raw material.

Due to this, recently, the scientists are focusing on the use of wool as raw material in other sectors of industry such as construction industry, pharmaceutical industry or even for re-launch the textile industry.

Products made from sheep wool can be used in construction in the form of mattress or rollers as heat or sound insulating materials.

Analyzing the wool's structure and its properties it is shown that the rejected wool in textile industry is exactly what is needed in the new fields of use, as thermal and acoustic insulation of buildings, for acoustic insulation in automotive and aviation and as a crop fertilizer in agriculture.

According to Order no. 2425/2016 of December 23, 2016, which regulates the Program for performing energy efficiency works, where the materials used are organic-natural and the sheep wool is one of them, an ideal solution for its capitalization at national level is presented.

The resumption of wool processing in textile industry entails high costs compared to 
its processing in the construction sector, where obtaining quality does not need great expense and it is not difficult goal to achieve.

The short-term and very short-term objective is the implementation of a center per region for washing, drying and treating sheep wool.

The establishment of those capitalization centers must pursue various aspects such as: type of wool packing (bulk or bale), water supply for washing, but also water outlet after treatement in the immediate vicinity of a watercourse.

\section{REFERENCES}

1. Creșterea animalelor, Centre de colectare a lânii identificate de direcțiile agricole județene, MADR - Ministerul Agriculturii și Dezvoltarii Rurale, accessed on 15 January 2018 and on 1 March 2018.

2. Doroftei F., (2006) Contribuții privind studiul performanțelor productive ale populațiilor de ovine din partea de est a țării luate în controlul oficial al producției, Teză de doctorat.
3. Food and Agriculture Organization of the United Nation statistics division, http://faostat.fao.org, accessed on 15 July 2018.

4. Government Decision (Hotărâre Guvern 500/2017), denumit "Ajutor de minimis pentru aplicarea programului de susţinere a crescătorilor de ovine pentru comercializarea lânii", publicat în Monitorul Oficial nr. 268 din 17 Iulie 2017.

5. Ilișiu E., Dărăban S., Radu R., Pădeanu I., Ilișiu V.-C., Pascal C., Rahmann G., (2013) The Romanian Tsigai sheep breed, their potential and the challenges for research, Landbauforsch Appl Agric Forestry Res 2 (63)161-170.

6. Institutul Național de Statistică, http://www.insse.ro, accessed on 15 July 2018.

7. Nica Th., Dermengi B., Ștefănescu C., (1965), Creșterea oilor, Editura Agro-Silvică, București.

8. Pascal C., (1998), Tehnologia creșterii ovinelor, Editura "Corson" Iaşi.

9. Pop A., Labușcă I., Petrescu R., Mochnacs M., (1983), Tehnologia creșterii ovinelor și caprinelor, Eitura Didactică și Pedagogică București.

10. Tolga, http://www.tolgawool.ro, accessed on 15 July 2018 